\title{
Properties of External Insulation Surface Preparation Mortar Using Expandable Graphite for Fire Resistance
}

\author{
Sung-Young Song ${ }^{1}$, Hwa-Sung Ryu ${ }^{2, *}$, Sang-Heon Shin ${ }^{2}$, Deuck-Mo Kim ${ }^{3}$ and \\ Won-Jun Park ${ }^{4, *(1)}$ \\ 1 Yoosong Engineering, Dongan-gu, Anyang 14054, Korea; ssy365@daum.net \\ 2 Hanyang Experiment and Consulting, Hanyang University, Ansan 15588, Korea; ssh8065@hanyang.ac.kr \\ 3 Hwarok Construction Industry, Hanyang University, Ansan 15588, Korea; golanhae@naver.com \\ 4 Department of Architectural Engineering, Kangwon National University, Samcheok 25913, Korea \\ * Correspondence: rhsung73@hanyang.ac.kr (H.-S.R.); wjpark@kangwon.ac.kr (W.-J.P.); \\ Tel.: +82-31-400-3752 (H.-S.R.); +82-33-570-6529 (W.-J.P.)
}

Received: 14 October 2019; Accepted: 2 December 2019; Published: 3 December 2019

\begin{abstract}
In the case of fire, surface treatment agents used in external insulation finishing methods are substances that are vulnerable to fire. This study examined the incorporation and applicability of expandable graphite in surface preparation mortar so that heat transfer to the surface part can be suppressed even when the cementitious surface preparation mortar is thinly constructed in the external insulation method. Experimental results showed that the mechanical properties of surface preparation mortar were improved by using the fly ash and silica fume. Surface treatment materials using expanded graphite have a characteristic of expanding when a fire occurs. It was experimentally confirmed that incorporating expanded graphite can reduce the phenomenon of heat penetration to the rear surface when the surface preparation mortar is exposed to high temperatures such as a flame.
\end{abstract}

Keywords: external insulation; surface preparation mortar; expandable graphite; fire resistance

\section{Introduction}

It is known that buildings account for a significant proportion of worldwide energy use and $\mathrm{CO}_{2}$ emissions. This has meant that the global demand for energy efficiency calls for improvements in the thermal performance of buildings [1,2]. External thermal insulation composite systems (ETICSs) consisting of insulation core and decorative surface materials are quite common in new constructions and refurbishment buildings with design-oriented goals of sustainability and energy efficiency [3]. Different types of thermal insulation materials such as expanded polystyrene (EPS) and mineral wool are among the products that can be used in ETICS solutions. In European countries, it is reported that most ETICS applications use EPS (82\%-83\%), or MW (11\%-12\%) [2-4]

However, the wide application of organic combustible insulation materials, such as EPS and extruded polystyrene (XPS) foams, also induces high fire hazards. Several standards, such as ISO (2002) 13785-2, NFPA 285, and BS 8414, have been developed to evaluate the fire safety of ETIS containing combustible components [4-7]. In the ETICS, also known as external insulation finishing systems (EIFSs), an external insulation method, the insulation is attached to the building envelope, surface treatment is performed for the exterior surface of the insulation, and the surface preparation mortar is constructed outside the insulation to protect the envelope of the insulation that may have a weak hardness. It is widely acknowledged that the general section design of an ETICS includes adhesives, EPS insulation material, cement, reinforcing mesh, and finishing materials [8-10]. Various research on ETICSs is focused on the probability of fire spread, fire safety, and fire barrier influence on ETICS reaction to fire performance. However, little knowledge is available on influence surface 
preparation mortar, reinforcing mesh, EPS thickness, and other treatment on the ETICS reactionto-fire performance [11-16].

The existing surface preparation mortar used in insulation construction is a cementitious surface preparation mortar, while the envelope consists of finishing materials using an acrylic emulsion $[17,18]$. The goal of using cementitious surface preparation mortar in the external insulation method is to flatten gaps or irregularities between the insulation through the plaster process after attaching the insulation, in addition to bonding the insulation to the concrete wall. Another goal is to secure an appropriate surface structure for the construction of the acrylic finishing material after applying the surface preparation mortar.

Accordingly, various procedures are required for the cementitious surface preparation mortar used in building external insulation methods. Typically, the adhesive strength level to secure the adhesive force of the insulation, the stability of the adhesive force according to changes in outside air temperature, and water resistance to prevent damage to the insulation due to permeation from the outside air are required. When using cementitious surface preparation mortar with low adhesion, the primary defect generated in the external insulation method is the reduction of the thermal conductivity of the insulation layer due to the exfoliation of the insulation or moisture permeation. To control the occurrence of such a defect, the bonding strength and hot and cold cycling strength of the cementitious surface preparation mortar used in the external insulation method are specified to be $1.1 \mathrm{~N} / \mathrm{mm}^{2}$ or more and the water absorption coefficient to be $0.2 \mathrm{~kg} / \mathrm{m}^{2} \mathrm{~h}^{0.5}$ or less (KS F 4716) $[19,20]$.

Meanwhile, researchers have proposed various methods to improve the fire resistance performance of the thermal insulation layer in the event of a fire in the wet external thermal insulation [21,22]. In the wet application method of the external thermal insulation, however, the thickness of the finishing material and the surface preparation mortar on the outer part of the insulation is approximately $3 \mathrm{~mm}$. Moreover, the fire resistance of the insulation is low in the event of a fire. While materials with a porous structure, such as lightweight insulation mortar, have the effect of suppressing heat penetration, when considering the thickness $(3 \mathrm{~mm}$ ) of the surface preparation mortar in the external insulation method, it is difficult to implement an appropriate surface structure during the construction process. In the event of a fire in a building applying external insulation with ignition inside or outside the building, heat from the flames penetrates the envelope finishing material and reaches the insulation. It then rises above the ignition point, ignites the insulation, and rapidly spreads the fire to the outer part along the outer wall.

Polystyrene foam insulation, in particular, the most widely used EPS material, ignites at approximately $550^{\circ} \mathrm{C}$ after liquefaction at $450{ }^{\circ} \mathrm{C}$, with a very high fire spreadability [4,23]. Conversely, phenol foam and urethane foam are combusted and carbonized at around $650{ }^{\circ} \mathrm{C}$, with relatively low fire spreadability compared to EPS. Between these, phenol foam is emerging as a major material in external insulation due to its smaller gas product during combustion and superior thermal performance to EPS. However, its use is limited due to high costs. In conclusion, to reduce the price required for external insulation and surface preparation mortar, lower the combustion diffusion rate, and improve construction performance, the heat penetration of the composite structure of the insulation material and cementitious surface preparation mortar must be suppressed.

On the other hand, the commonly used supporting materials include high-density polyethylene and styrene-butadiene-styrene, expanded graphite (EG), etc. Compared with the polymeric supporting materials, EG has the advantages of high thermal conductivity and good adsorption ability, thus making it a good matrix for preparing composites, such as cementitious surface preparation mortar [24,25]. EG presents the lowest cost due to limited treatments and has desirable performances of high thermal conductivity, high stability, lower weight density, and good compatibility [26-29]. Graphite in both micro and nano-scale sizes is known as a flame retardant because of its covalently bonded hexagonal structure. The chemically modified EG, however, appears as a superior flame retardant benefiting from its exfoliation potential. There are numerous examples demonstrating the excellence of EG as a commercially available flame retardant for various matrices [30-32]. 
Accordingly, this study seeks to investigate the physical-mechanical properties of the insulation layer of the external insulation method, which consists of (1) phenol foam, (2) EPS, (3) glass fiber mesh, and (4) EG-incorporated surface preparation mortar on the outer wall side. This study examined the incorporation and applicability of EG in the surface preparation mortar so that heat transfer to the surface part can be suppressed even when the cementitious surface preparation mortar is thinly constructed in the external insulation method. In addition, this study secondarily examined the incorporation and application of fly ash and silica fume to prevent a decrease in physical-mechanical performance due to the incorporation of EG. Furthermore, in the surface preparation mortar strengthening process, in which the material is attached before applying the surface preparation mortar to the outer part of the insulation, glass fiber mesh is required in common to prevent cracking and to increase tensile strength. After attaching the mesh, the EG-incorporated surface preparation mortar was applied to the outer part of the insulation formed by the two-stage structure of phenol foam and EPS and exposed to the flame to evaluate the combustion characteristics.

\section{Materials and Methods}

\subsection{Experimental Materials-Surface Preparation Mortar}

The cement used in this study was one type of ordinary Portland cement (OPC), with a specific gravity of 3.15. The chemical properties of the OPC are shown in Tables 1 and 2 below. The physical properties of the OPC are shown in Table 2. Table 3 summarizes the granularity and composition of aggregates used in the surface preparation mortar. For the surface preparation mortar, a half-liquid paste is prepared in which an emulsified acrylic resin and aggregate are incorporated, into which cement is then incorporated. Table 4 shows the physical properties of the acrylic resin used in the emulsified acrylic resin. The emulsion added to the acrylic resin consisted of a moisturizer, a thickener, and an antifoaming agent. The composition of the emulsified acrylic resin used as a binder with cement is shown in Table 5.

Table 1. Chemical composition of ordinary Portland cement (unit: $w t \%)$.

\begin{tabular}{cccccccc}
\hline $\mathrm{SiO}_{2}$ & $\mathrm{Al}_{2} \mathrm{O}_{3}$ & $\mathrm{CaO}$ & $\mathrm{MgO}$ & $\mathrm{SO}_{3}$ & $\mathrm{~K}_{2} \mathrm{O}$ & $\mathrm{Na}_{2} \mathrm{O}$ & $\mathrm{Fe}_{2} \mathrm{O}_{3}$ \\
\hline 21.09 & 4.84 & 63.85 & 3.32 & 3.09 & 1.13 & 0.29 & 2.39 \\
\hline
\end{tabular}

Table 2. Physical properties of ordinary Portland cement.

\begin{tabular}{|c|c|c|c|c|c|c|}
\hline \multirow{2}{*}{$\begin{array}{l}\text { Density } \\
\left(20^{\circ} \mathrm{C}\right)\end{array}$} & \multirow{2}{*}{$\begin{array}{c}\text { Blaine Fineness } \\
\text { Specific Surface } \\
\text { Area }\left(\mathrm{cm}^{2} / \mathrm{g}\right)\end{array}$} & \multicolumn{2}{|c|}{ Setting Time } & \multicolumn{3}{|c|}{ Compressive Strength of Mortar (MPa) } \\
\hline & & $\begin{array}{c}\text { Initial Set } \\
\text { (hour) }\end{array}$ & $\begin{array}{c}\text { Final Set } \\
\text { (hour) }\end{array}$ & 3 days & 7 days & 28 days \\
\hline $3.15 \mathrm{~g} / \mathrm{cm}^{3}$ & 3400 & 4 & 7 & 20 & 23 & 38 \\
\hline
\end{tabular}

Table 3. Composition of dolomite aggregate.

\begin{tabular}{ccccc}
\hline Size $(\mathbf{m m})$ & $\mathbf{0 . 6} \mathbf{0 . 8 5}$ & $\mathbf{0 . 2 5} \mathbf{0 . 6}$ & $\mathbf{0 . 1} \sim \mathbf{0 . 2 5}$ & $\mathbf{0 . 0 7 5} \mathbf{0 . 1}$ \\
\hline Rate $(\%)$ & 19.74 & 40.78 & 13.16 & 26.32 \\
\hline
\end{tabular}

Table 4. Specification of acrylic resin.

\begin{tabular}{cccc}
\hline Color & Solid Content (\%) & Viscosity (mPa.S) & pH $\left(20^{\circ} \mathrm{C}\right)$ \\
\hline White & 48 & 102 & 9.0 \\
\hline
\end{tabular}


Table 5. Composition of emulsified acrylic resin (unit: wt\%).

\begin{tabular}{ccccc}
\hline Acrylic Resin & Butyl Carbitol & Antifoaming Agent & Ethylene Glycol & Methyl Cellulose \\
\hline 93.86 & 3.25 & 0.36 & 1.44 & 1.09 \\
\hline
\end{tabular}

EG was used to provide expandability of the surface preparation mortar. Table 6 below shows the properties of EG used in this experiment. EG is primarily used as a flame retardant; voids are generated due to the expansion of carbon interlayer bonds during combustion in organic materials, and the material can also suppress heat transfer. The EG used in this study has a particle size of $173 \mu \mathrm{m}$ and an expansion rate of $100 \%-250 \%$. In addition, a foaming start temperature was used $180-200{ }^{\circ} \mathrm{C}$.

The glass fiber mesh is attached before applying the surface preparation mortar to the outer part of the insulation in the surface preparation mortar strengthening process. This is used to prevent cracking and increase tensile strength during the hardening of the surface preparation mortar. The glass fiber serves as a protective layer at the outer part of the insulation. This study used the glass fiber mesh of $900 \mathrm{MPa}$ of tensile strength. Table 7 shows the physical properties of the glass fiber mesh. Meanwhile, fly ash and silica fume were used as the main materials for the admixtures of the background surface preparation mortar. The main physical properties are shown in Table 8 below.

Table 6. Specification of expandable graphite.

\begin{tabular}{cccc}
\hline Carbon Content (wt $\%)$ & Expansion Rate (\%) & Starting Temperature $\left({ }^{\circ} \mathbf{C}\right)$ & Particle Size $(\mu \mathrm{m})$ \\
\hline 92 & $100 \sim 250$ & $200 \sim 250$ & 173 \\
\hline
\end{tabular}

Table 7. Physical properties of glass fiber mesh.

\begin{tabular}{ccccc}
\hline Moisture Regain (\%) & Density $\left(\mathbf{g} / \mathrm{cm}^{\mathbf{3}}\right)$ & Loss of Ignition (\%) & Tensile Strenth (MPa) & Mesh Size (mm) \\
\hline$<0.06$ & 2.54 & $0.7 \pm 0.15$ & 900 & 4 \\
\hline
\end{tabular}

Table 8. Specification of fly ash and silica fume.

\begin{tabular}{ccc}
\hline Type & Fly Ash & Silica Fume \\
\hline $\mathrm{SiO}_{2}$ & $41.20 \%$ & $95.90 \%$ \\
$\mathrm{Al}_{2} \mathrm{O}_{3}$ & $14.70 \%$ & $0.00 \%$ \\
$\mathrm{CaO}$ & $16.00 \%$ & $1.01 \%$ \\
$\mathrm{MgO}$ & $1.36 \%$ & $0.09 \%$ \\
$\mathrm{~K}_{2} \mathrm{O}$ & $2.38 \%$ & $0.44 \%$ \\
$\mathrm{Na}_{2} \mathrm{O}$ & $0.61 \%$ & $0.00 \%$ \\
$\mathrm{Fe}_{2} \mathrm{O}_{3}$ & $18.10 \%$ & $0.18 \%$ \\
$\mathrm{SO}_{3}$ & $1.03 \%$ & $0.11 \%$ \\
Loss of ignition & $1.60 \%$ & $0.70 \%$ \\
Density $\left(\mathrm{g} / \mathrm{cm}^{3}\right)$ & 2.2 & 2.1 \\
Blain $\left(\mathrm{g} / \mathrm{cm}^{3}\right)$ & 2800 & $150,000 \sim 250,000$ \\
\hline
\end{tabular}

\subsection{Test Specimen}

Finally, the insulation used in this study comprised a combination of phenol foam and EPS, while the insulation test specimen consisted of $30 \mathrm{~mm}$ of phenol foam and $60 \mathrm{~mm}$ of EPS. On the surface of the phenol foam, a thermal insulation structure was fabricated using surface preparation mortar reinforced with the glass fiber mesh. Table 9 below shows the physical properties of the insulation material used in the insulation specimen. 
Table 9. Specification of insulation.

\begin{tabular}{ccc}
\hline Type & Phenol Foam & EPS \\
\hline Color & Pink & White \\
Thermal Conductivity (Kcal.m.K) & 0.019 & 0.036 \\
Density (kg/cm $\left.{ }^{3}\right)$ & 36 & 30 \\
Flexural Strength (Mpa) & 23.3 & 35 \\
Material & Phenol & Styrene \\
\hline
\end{tabular}

\section{Experiment Outline}

\subsection{Evaluation Items}

This experiment proceeded in two steps. Firstly, the reduction in strength was evaluated after incorporating the EG in the cementitious surface preparation mortar. To compensate for the reduction in strength caused by the incorporation of the EG, fly ash and silica fume were incorporated to improve the strength performance. Secondly, the cementitious surface preparation mortar was applied to the outer part of the insulation, after which the temperature of the insulation was measured according to the exposure time to the flame to evaluate the characteristics of the fire-delayed surface preparation mortar. Table 10 below shows the experimental procedure.

Table 10. Experiment process.

\begin{tabular}{lc}
\hline \multicolumn{1}{c}{ Experiment Step } & Evaluation Index \\
\hline (1) Characteristics of graphite incorporation & $\begin{array}{c}\text { Adhesion in tension } \\
\text { Freeze thawing } \\
\text { Water absorption Coefficient }\end{array}$ \\
\hline (2) Fly ash and silica fume incorporation to improve performance & $\begin{array}{c}\text { Adhesion in tension } \\
\text { Freeze thawing } \\
\text { Water absorption Coefficient }\end{array}$ \\
\hline (3) Characteristics of graphite incorporation & $\begin{array}{c}\text { Adhesion in tension } \\
\text { Freeze thawing }\end{array}$ \\
\hline (4) Characteristics of heat transfer delay & Water absorption Coefficient \\
\hline
\end{tabular}

\subsection{Surface Preparation Mortar Formulation}

Table 11 below shows the formulation of surface preparation mortar used in this research and development. A half-liquid paste in which the acrylic emulsion and aggregate were incorporated was prepared, after which the cement was incorporated. The fly ash and silica fume were used to improve the physiodynamic performance, after which the surface preparation mortar was formulated using EG as a flame retardant.

Table 11. Experimental factors and levels in this study (unit: g).

\begin{tabular}{|c|c|c|c|c|c|c|c|c|}
\hline Specimen & Sand & Fly Ash & $\begin{array}{l}\text { Silica } \\
\text { Fume }\end{array}$ & $\begin{array}{c}\text { Expandable } \\
\text { Graphite }\end{array}$ & Emulsion & $\begin{array}{c}\text { Methyl } \\
\text { Cellulose }\end{array}$ & Water & OPC \\
\hline Plain & 1140 & 0 & 0 & 0 & & & & 2000 \\
\hline EG05 & 1083 & & & 57 & & & & 2000 \\
\hline EG10 & 1026 & & & 114 & & & & 2000 \\
\hline EG15 & 969 & & & 171 & 180 & 6 & 280 & 2000 \\
\hline EG20 & 912 & & & 228 & & & & 2000 \\
\hline F05 & 1083 & 57 & 0 & 0 & & & & 2000 \\
\hline F10 & 1026 & 114 & 0 & 0 & & & & 2000 \\
\hline
\end{tabular}


Table 11. Cont.

\begin{tabular}{|c|c|c|c|c|c|c|c|c|}
\hline Specimen & Sand & Fly Ash & $\begin{array}{l}\text { Silica } \\
\text { Fume }\end{array}$ & $\begin{array}{l}\text { Expandable } \\
\text { Graphite }\end{array}$ & Emulsion & $\begin{array}{l}\text { Methyl } \\
\text { Cellulose }\end{array}$ & Water & OPC \\
\hline F15 & 969 & 171 & 0 & 0 & & & & 2000 \\
\hline F20 & 912 & 228 & 0 & 0 & & & & 2000 \\
\hline F10S1 & 1014.6 & 114 & 11.4 & 0 & & & & 2000 \\
\hline F10S3 & 991.8 & 114 & 34.2 & 0 & & & & 2000 \\
\hline F10S5 & 969 & 114 & 57 & 0 & 180 & 6 & 280 & 2000 \\
\hline FSEG05 & 934.8 & 114 & 34.2 & 57 & & & & 2000 \\
\hline FSEG10 & 877.8 & 114 & 34.2 & 114 & & & & 2000 \\
\hline FSEG15 & 820.8 & 114 & 34.2 & 171 & & & & 2000 \\
\hline FSEG20 & 763.8 & 114 & 34.2 & 228 & & & & 2000 \\
\hline
\end{tabular}

\subsection{Experimental Configuration}

\subsubsection{Bonding Strength}

For the bonding strength test of the test specimen according to the formulation, $70 \mathrm{~mm} \times 70 \mathrm{~mm}$ specimens were prepared and subjected to standard curing under RH $60 \%$ and $20 \pm 2{ }^{\circ} \mathrm{C}$ according to KS F 4716, after which the bonding strength at 14 days of age was measured. Figure 1 below shows the bonding strength test specimen $[19,20]$.

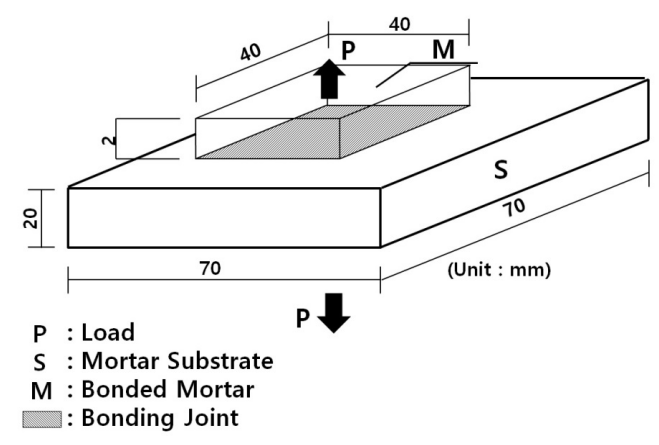

(a)

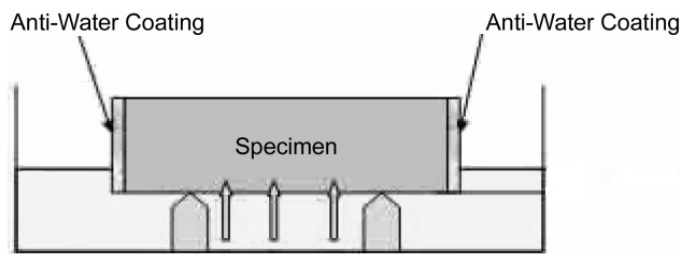

(b)

Figure 1. Schema of test and specimen: (a) bonding strength test; (b) water absorption test.

\subsubsection{Water Absorption Coefficient}

The water absorption coefficient is a proportional coefficient between the water absorption per area of material $\left(\mathrm{kg} / \mathrm{m}^{2}\right)$ and the time $(\sqrt{t})$. To measure the water absorption coefficient, a test specimen was prepared according to the KS F 4716 standard. For this purpose, a $3 \mathrm{~mm}$ surface preparation mortar was applied on the surface of a circular test specimen with a diameter of $150 \mathrm{~mm}$ and a thickness of $40 \mathrm{~mm}$. The water absorption coefficient of the produced test specimen was measured according to KS F 2609. The amount of absorption per area over time when one side of the material is in contact with water is as follows $[33,34]$

$$
\mathrm{m}=\mathrm{w} \cdot \sqrt{t}
$$

where, m: water absorption per unit area $\left(\mathrm{kg} / \mathrm{m}^{2}\right)$, w: water absorption coefficient $\left(\mathrm{kg} / \mathrm{m}^{2} 0.5\right)$, and $\mathrm{t}$ : time (h)

\subsubsection{Hot and Cold Cycling Test}

In the hot and cold cycling test of the surface preparation mortar, a mortar test specimen of $70 \mathrm{~mm} \times 70 \mathrm{~mm} \times 20 \mathrm{~mm}$ was prepared according to KS F 4716, after which the surface preparation mortar was applied at $3 \mathrm{~mm}$ to the outer part. Firstly, the specimen was immersed in water of $20 \pm 2{ }^{\circ} \mathrm{C}$ 
for $18 \mathrm{~h}$, immediately cooled for $3 \mathrm{~h}$ in a constant temperature chamber of $-20 \pm 3^{\circ} \mathrm{C}$, and then heated for $3 \mathrm{~h}$ in another constant temperature chamber of $50 \pm 3^{\circ} \mathrm{C}$. Twenty-four hours of the above process was set as one cycle, and the bonding strength was measured after 10 cycles.

\subsubsection{Flame Exposure Test}

To evaluate the characteristics of the insulation surface due to the flame exposure of the surface preparation mortar, the prepared insulation of the test specimen was adhered with $60 \mathrm{~mm}$ of EPS and $30 \mathrm{~mm}$ of phenol foam, after which it was cut at a width of $15 \mathrm{~cm}$ and height of $50 \mathrm{~cm}$. Subsequently, the glass fiber mesh was applied to the outer part of the phenol foam and $3 \mathrm{~mm}$ of the surface preparation mortar was applied, thus completing the surface part. EPS ignites at approximately $550{ }^{\circ} \mathrm{C}$ after liquefaction at $450^{\circ} \mathrm{C}$, with a high fire spreadability [4,23]. Conversely, phenol foam and urethane foam are combusted and carbonized at around $650^{\circ} \mathrm{C}$, with relatively low fire spreadability compared to EPS. The specimen surface was then exposed to a $700{ }^{\circ} \mathrm{C}$ flame for $15 \mathrm{~min}$ at a distance of $70 \mathrm{~mm}$. A thermocouple was installed in each of the EPSs and phenol foams using a K-type thermocouple, and the temperature change at each point after exposure to the flame for $15 \mathrm{~min}$ was measured. After $15 \mathrm{~min}$ of flame exposure, the expansion thickness of the surface preparation mortar was measured at room temperature. Figure 2 shows the cross-section of the specimen in the flame exposure test.

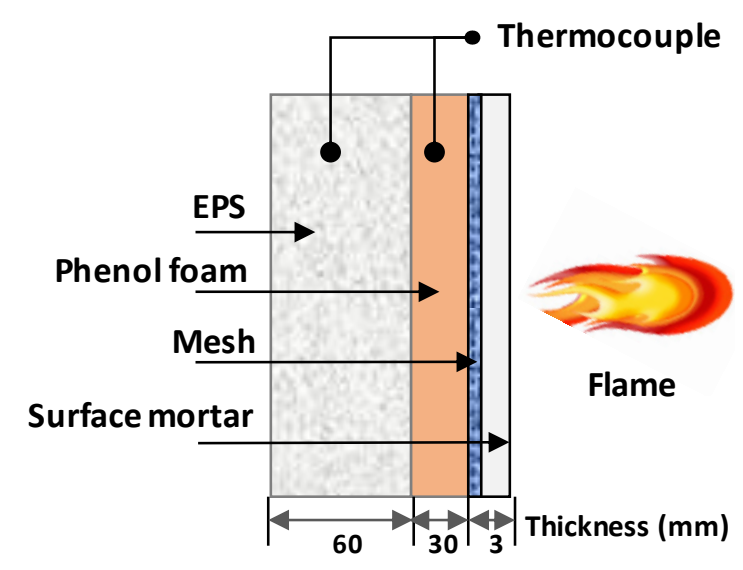

Figure 2. Outline of flame exposure test.

\section{Experimental Results and Discussion}

\subsection{Bonding Strength}

Figure 3 shows the results of the bonding strength test. The minimum bonding strength required in KS F 4716 is $1.1 \mathrm{~N} / \mathrm{mm}^{2}$; the plain bonding strength was approximately $0.4 \mathrm{~N} / \mathrm{mm}^{2}$ at an age of one day and $1.8 \mathrm{~N} / \mathrm{mm}^{2}$ at 14 days. When incorporating the EG in plain, the bonding strength at an age of one day with a $5 \%$ incorporation was approximately $0.2 \mathrm{~N} / \mathrm{mm}^{2}$ and it reached $1.1 \mathrm{~N} / \mathrm{mm}^{2}$ at 14 days. However, when incorporating more than $10 \%$ EG, it was impossible to measure the strength due to adhesion loss at the age of one day. At 14 days of age, the adhesion was below the standard strength. EG particles are non-hydrated carbon materials, existing only as physical fillers during the hydration process. Consequently, the surface preparation mortar lowers the anchoring of the surface part and exists as an impurity in the generation of the hydration material, thus reducing the strength. When the fly ash was incorporated into the surface preparation mortar at $20 \%$, the bonding strength at the age of one day was $0.6 \mathrm{~N} / \mathrm{mm}^{2}$. At $10 \%$ fly ash and $1 \%, 3 \%$, and $5 \%$ silica fume, the bonding strength increased to $0.7 \mathrm{~N} / \mathrm{mm}^{2}$ at one day old, which was slightly higher than that of the fly ash incorporation alone. At 14 days, the maximum strength of the test specimen containing only fly ash was approximately $2.4 \mathrm{~N} / \mathrm{mm}^{2}$; when silica fume was incorporated at $3 \%$, however, the bonding strength was $2.9 \mathrm{~N} / \mathrm{mm}^{2}$. The bonding strength at $5 \%$ substitution of silica fume was not significantly 
different from that of a $3 \%$ substitution of silica fume. The circular particles of fly ash and silica fume are also considered to improve strength through anchoring, which enables the surface preparation mortar to tighten the vulnerable microspaces of the concrete interface [35]. When incorporating EG in the formulation containing $15 \%$ fly ash and 3\% silica fume, the 1-day bonding strength and 14-day bonding strength gradually decreased as the incorporation rate increased. However, all formulations exhibited strength greater than $1.1 \mathrm{~N} / \mathrm{mm}^{2}$ at 14 days of age.

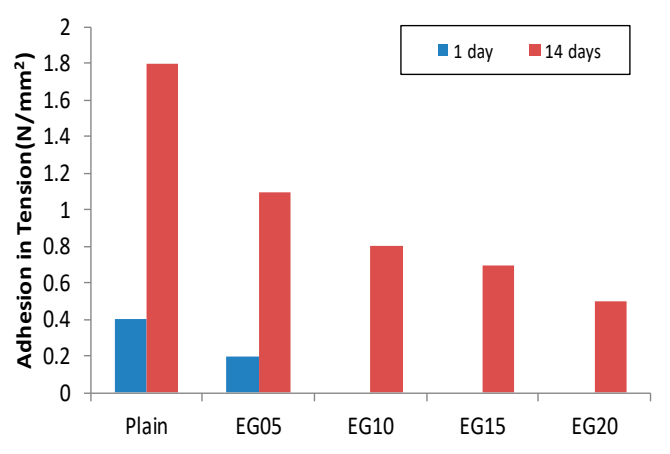

(a)

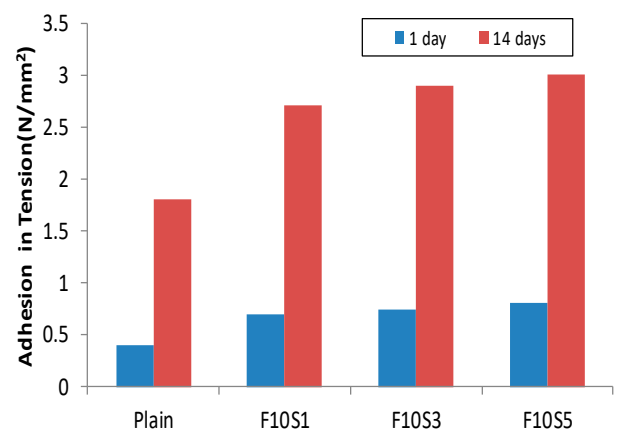

(c)

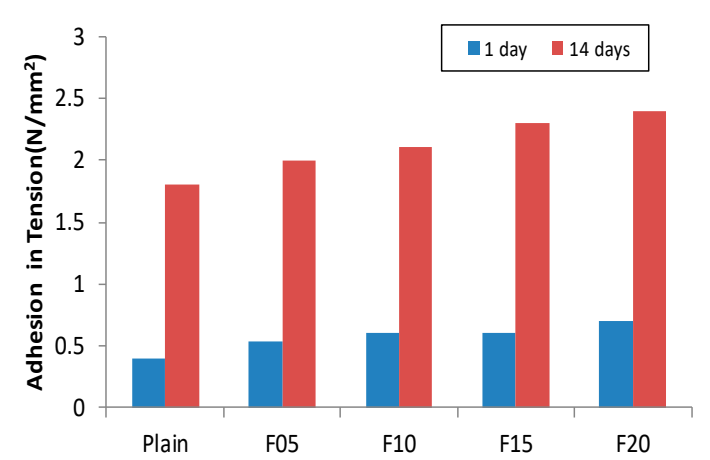

(b)

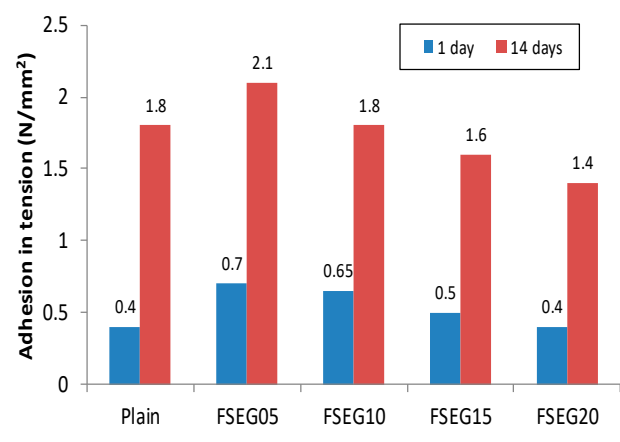

(d)

Figure 3. Adhesion in tension: (a) expandable graphite; (b) fly ash; (c) fly ash + silica fume; (d) fly ash + silica fume + expanded graphite.

When incorporating more than $15 \%$ of EG, a lower bonding strength than the plain was shown. When incorporating EG, the performance fell below KS standard due to the decrease in strength; however, by mixing fly ash and silica fume, it was possible to increase the strength of the surface preparation mortar with improved physical performance similar to that of the existing surface preparation mortar up to a $10 \%$ incorporation rate of EG. The bonding strength test confirmed that the incorporation of EG affects the reduction in bond strength of the surface preparation mortar and that the incorporation of silica fume and fly ash supplements the bonding strength of the surface preparation mortar.

\subsection{Bonding Strength After Hot and Cold Cycling}

Figure 4 is a graph of the bonding strength of the surface preparation mortar after 10 days of hot and cold cycling. The cementitious surface preparation mortar used in the external insulation method is installed on the outer part of the insulation; thus, its strength decreases due to expansion and contraction owing to changes in the outside air temperature. When EG is incorporated, the bonding strength decreased as the incorporation rate increased. Even at the lowest incorporation rate of $5 \%$, the exhibited strength of $0.6 \mathrm{~N} / \mathrm{mm}^{2}$ was lower than the standard strength, making it impossible to use as a surface preparation mortar. Meanwhile, incorporating fly ash resulted in higher bonding strength than plain, increasing to $1.4 \mathrm{~N} / \mathrm{mm}^{2}$ at $15 \%$ substitution. When $15 \%$ of fly ash was incorporated with $1 \%$ 
silica fume, the bonding strength was $1.6 \mathrm{~N} / \mathrm{mm}^{2}$ or more, confirming an improvement in performance. When both the fly ash and silica fume were incorporated in the surface preparation mortar and the EG was substituted at $5 \%$, the bonding strength was $1.3 \mathrm{~N} / \mathrm{mm}^{2}$. For plain, when $5 \%$ of EG was substituted, the reduction in bonding strength was about $46 \%$. However, for the surface preparation mortar improved with silica fume and fly ash, when $5 \%$ of EG was substituted, the bonding strength reduction was about $34 \%$. When incorporating fly ash and silica fume, the hydration structure is tightened and the anchoring effect of adhesion interface is enhanced, thus suppressing the decrease in strength when incorporating EG in hot and cold cycling [36].

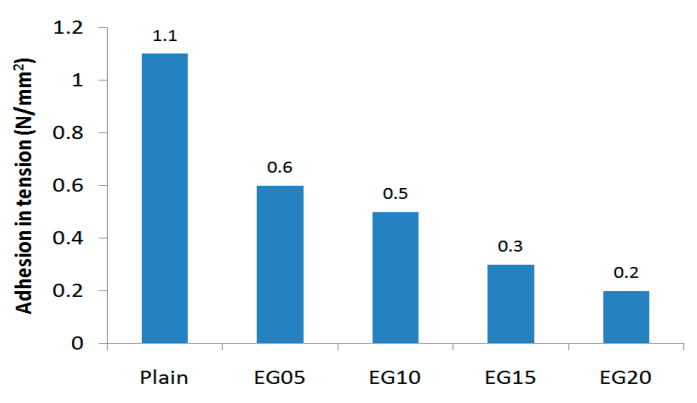

(a)

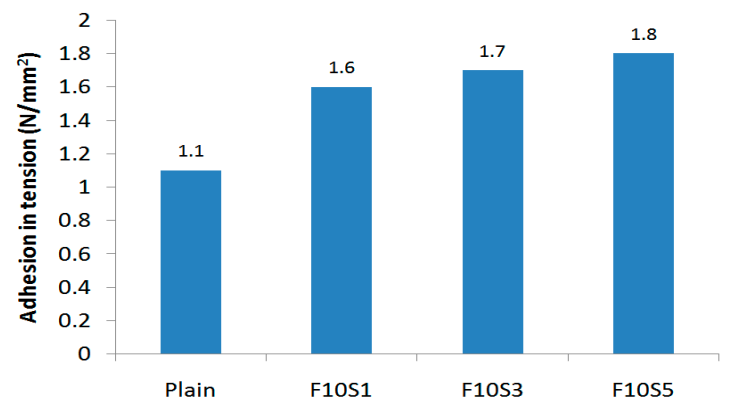

(c)

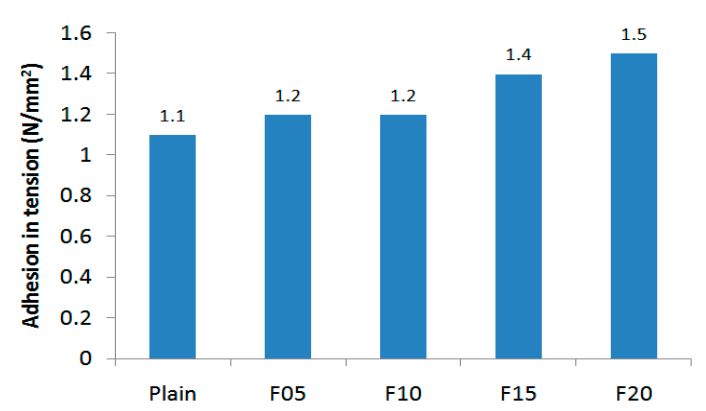

(b)

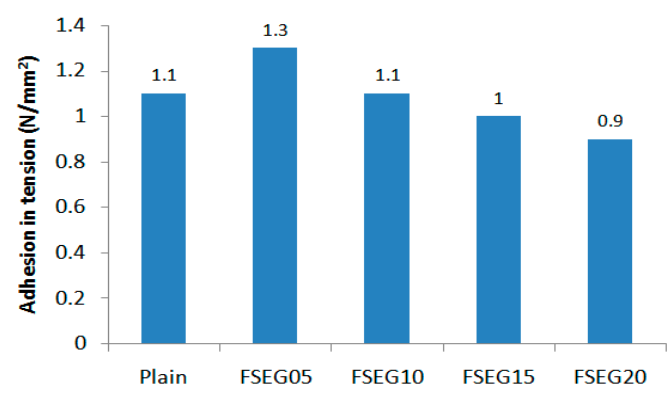

(d)

Figure 4. Adhesion in tension according to freeze-thawing: (a) expandable graphite; (b) fly ash; (c) fly ash + silica fume; (d) fly ash + silica fume + expanded graphite

\subsection{Water Absorption Coefficient}

Figure 5 shows the water absorption coefficient measurements of the surface preparation mortar. The plain water absorption coefficient was $0.07 \mathrm{~kg} / \mathrm{m}^{2} \mathrm{~h}^{0.5}$, which is much lower than the KS 4716-required water absorption coefficient of $0.2 \mathrm{~kg} / \mathrm{m}^{2} \mathrm{~h}^{0.5}$. When $5 \%$ of EG is incorporated, the water absorption coefficient is approximately twice that of plain. Furthermore, the coefficient was $0.25 \mathrm{~kg} / \mathrm{m}^{2}$ $\mathrm{h}^{0.5}$ when incorporating $15 \% \mathrm{EG}$, higher than the KS standard water absorption coefficient. To reduce the water absorption coefficient, the incorporation of fly ash was minimal at $10 \%$, and when incorporating $15 \%$ fly ash or more, the water absorption coefficient was higher than plain. When incorporating silica fume for $15 \%$ fly ash, the water absorption coefficient decreased as the incorporation rate of silica fume increased. Here, when incorporating the EG into the surface preparation mortar improved with 15\% fly ash and 3\% silica fume, the water absorption coefficient increased as the incorporation rate of the EG increased. From 15\% of EG incorporation, however, the water absorption coefficient exceeded $0.1 \mathrm{~kg} / \mathrm{m}^{2} \mathrm{~h}^{0.5}$. 


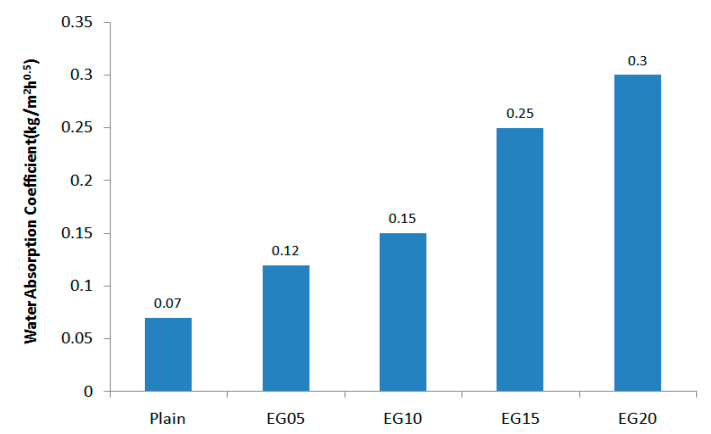

(a)

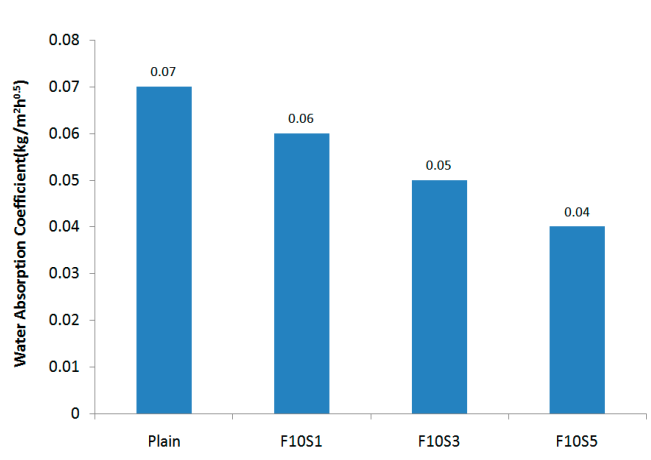

(c)

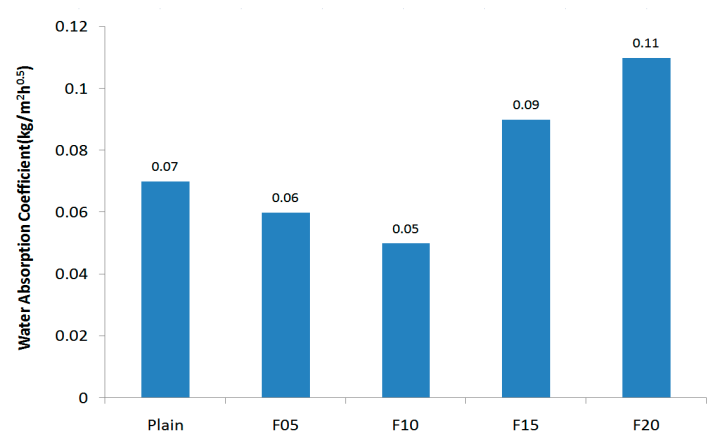

(b)

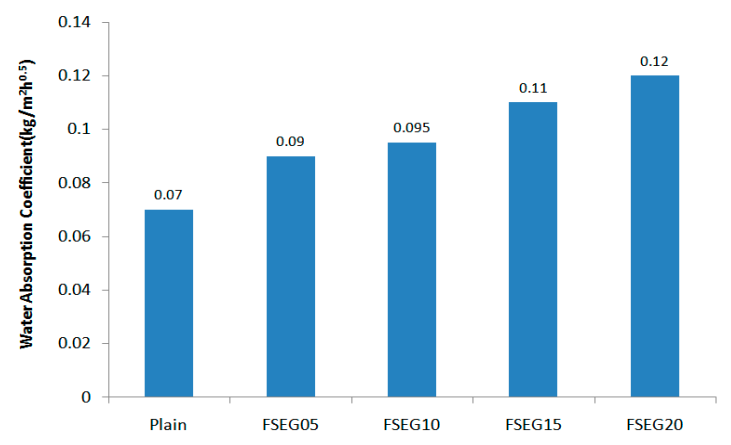

(d)

Figure 5. Water absorption coefficient: (a) expandable graphite; (b) fly ash; (c) fly ash + silica fume; (d) fly ash + silica fume + expanded graphite.

In terms of the water absorption coefficient of the surface preparation mortar, permeability was found to increase above a certain incorporation rate in the case of fly ash, which has lower fineness than cement. Silica fume, which has higher fineness than cement, is considered to be effective in suppressing water permeability due to the reduction of micropores when the fineness is $150,000 \mathrm{~g} / \mathrm{cm}^{3}$ or less (i.e., $0.1 \mu \mathrm{m}$ or less). However, as the particle size of the EG is $178 \mu \mathrm{m}$, which is larger than the cement particles, and does not have a hydration reaction, it is considered that the particle filling properties are reduced.

\subsection{Flame Exposure Surface Characteristics}

Table 12 shows the measurements of the temperature change of the external insulation system exposed to flame for $15 \mathrm{~min}$ and the surface expansion thickness of the surface preparation mortar. For plain, the internal temperature of the phenol foam rose to $750{ }^{\circ} \mathrm{C}$, higher than the flame temperature. This temperature rise is attributed to the phenol foam being burned by the external flame. The temperature rose to $600{ }^{\circ} \mathrm{C}$ at the rear of the phenol foam, and then the EPS layer collapsed. In FSEG05 and FSEG10, while the central temperature of the phenol foam rose to the carbonization temperature, the temperature of the rear part was maintained below $450{ }^{\circ} \mathrm{C}$, the temperature before thermal decomposition of EPS. Consequently, the EPS layer did not collapse. The surface preparation mortar incorporating the EG appeared to have a carbide layer with an expanded surface area of approximately 8 to $10 \mathrm{~mm}$ when contacting the external flame. Figure 6 shows the insulation finish surface after exposure to the flame. When using a general surface preparation mortar, the surface preparation mortar of the surface was lost due to the flame, thus exposing the insulation surface. As a result, the phenol foam at the rear surface was burned. However, the surface preparation mortar using the EG was maintained without losing the surface part, thereby keeping the insulation at the 
rear from becoming exposed. The carbonized layer formed by the EG was found to be able to suppress the combustion of phenol foam at the outer part of the insulation.

Table 12. The temperature change of the insulation system and expanded depth of surface preparation mortars after $15 \mathrm{~min}$ of flame exposure.

\begin{tabular}{ccccc}
\hline Specimen & Flame & Thermo Couple-1 & Thermo Couple-2 & $\begin{array}{c}\text { Expanded Depth of Surface } \\
\text { Preparation Mortars }\end{array}$ \\
\hline Plain & $700^{\circ} \mathrm{C}$ & $750{ }^{\circ} \mathrm{C}$ & $600^{\circ} \mathrm{C}$ & 0 \\
FSEG05 & $700^{\circ} \mathrm{C}$ & $670^{\circ} \mathrm{C}$ & $430{ }^{\circ} \mathrm{C}$ & $8 \mathrm{~mm}$ \\
FSEG10 & $700^{\circ} \mathrm{C}$ & $650^{\circ} \mathrm{C}$ & $400^{\circ} \mathrm{C}$ & $10 \mathrm{~mm}$ \\
\hline
\end{tabular}

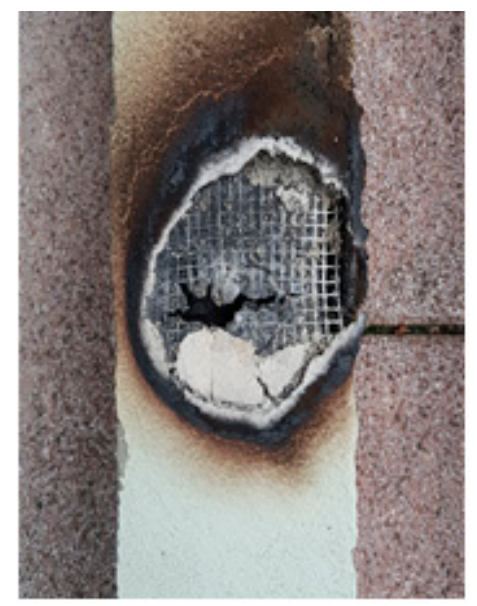

(a)

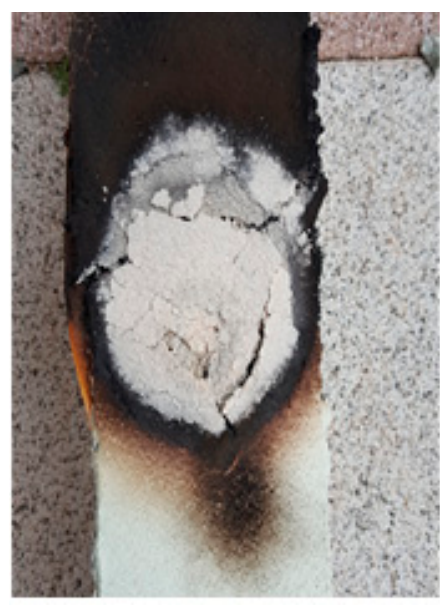

(b)

Figure 6. Insulation surface of flame exposed: (a) ordinary surface preparation materials. Expandable graphite; (b) surface preparation materials using expandable graphite.

\section{Conclusions}

The results of the experimental evaluation of the characteristics of cementitious surface preparation mortar incorporating fly ash, silica fume, and EG to improve the performance of the surface preparation mortar of wet external insulation and the insulation finish are summarized as follows. The surface preparation mortar used in the exterior insulation finishing methods is a material vulnerable to fire due to its thin finish and combustion, which causes the surface to rapidly collapse. In this study, it was expected that the performance of the surface preparation mortar could be improved through EG with excellent flame resistance. The experiments demonstrated that while the surface preparation mortar using EG had problems, such as reduced bond strength and water absorption coefficient, its physical performance was improved by using fly ash and silica fume. In the surface preparation mortar using EG, the phenol foam on the surface of the composite insulation specimen showed no surface punctures due to the flame, thus potentially reducing the penetration of the heat source.

For the surface preparation mortar incorporating only EG, the bonding strength, hot and cold cycling strength, and water absorption coefficient were found to be lower than the standard. When incorporating fly ash and silica fume, the bonding strength, hot and cold cycling strength, and water absorption coefficient of the surface preparation mortar were improved; with fly ash incorporation of $15 \%$ and silica fume of $3 \%$, excellent physical properties were achieved.

When using fly ash and silica fume and up to $10 \%$ of EG was incorporated into the improved surface preparation mortar, physical properties higher than the required performance for surface preparation mortar were attained. Furthermore, this study experimentally confirmed that incorporating EG can reduce the phenomenon of heat penetration to the rear surface when the surface preparation 
mortar is exposed to high temperatures, such as from a flame, thus causing the surface preparation mortar to collapse.

Author Contributions: For research articles, author contributions are as follows; conceptualization, S.-Y.S. and H.-S.R.; methodology and investigation, D.-M.K.; data curation, S.-H.S.; writing-original draft preparation, S.-Y.S.; writing and editing, H.-S.R. and W.-J.P.

Acknowledgments: This research was supported by the grant number (18CTAP-C130219-03) through the Korea Agency for Infrastructure Technology Advancement funded by the Ministry of Land, Infrastructure, and Transport of the Korean government.

Conflicts of Interest: The authors declare that there is no conflict of interest regarding the publication of this paper.

\section{References}

1. European Commission. Mapping and Analyses of the Current and Future (2020-2030) Heating/Cooling fuel Deployment (Fossil/Renewables); European Commission: Brussels, Belgium, 2016.

2. Gonçalves, M.; Simões, N.; Serra, C.; Flores-Colen, I. A review of the challenges posed by the use of vacuum panels in external insulation finishing systems. Appl. Energy 2020, 257, 1-15. [CrossRef]

3. Pasker, R. The European ETICS market—Facts \& Figures; European ETICS Forum: London, UK, 2015.

4. Zhoua, B.; Yoshioka, H.; Noguchi, T.; Ando, T. Experimental study of expanded polystyrene (EPS) External Thermal Insulation Composite Systems (ETICS) masonery façade reaction-to-fire performance. Therm. Sci. Eng. Prog. 2018, 8, 83-92. [CrossRef]

5. International Standard Organization. ISO 13785-2, Reaction-to-fire Tests for Facades Part 2: Large-Scale Test; International Standard Organization: Geneva, Switzerland, 2002.

6. National Fire Protection Association. NFPA 285, Standard Fire Test Method for Evaluation of Fire Propagation Characteristics of Exterior Non-Load-Bearing Wall Assemblies Containing Combustible Components; National Fire Protection Association: Quincy, MA, USA, 2012.

7. BSI Group. BS 8414-1, Fire Performance of External Cladding Systems Test Methods for Nonload bearing external cladding systems applied to the face of a building; BSI Group: London, UK, 2002.

8. Barreira, E.; Freitas, V.P. Experimental study of the hygrothermal behaviour of External Thermal Insulation Composite Systems (ETICS). Build. Environ. 2013, 63, 31-39. [CrossRef]

9. Nilica, R.; Harmuth, H. Mechanical and fracture mechanical characterization of building materials used for external thermal insulation composite systems. Cem. Concr. Res. 2005, 35, 1641-1645. [CrossRef]

10. Peng, L.; Ni, Z.; Huang, X. Review on the fire safety of exterior wall claddings in high- rise buildings in China. Procedia Eng. 2013, 62 (Suppl. C), 663-670. [CrossRef]

11. Doroudiani, S.; Omidian, H. Environmental, health and safety concerns of decorative mouldings made of expanded polystyrene in buildings. Build. Environ. 2010, 45, 647-654. [CrossRef]

12. Huang, X.; Wang, Q.; Zhang, Y.; Yin, Y.; Sun, J. Thickness effect on flame spread characteristics of expanded polystyrene in different environments. J. Thermoplast. Compos. Mater. 2012, 25, 427-438. [CrossRef]

13. Chen, Y.F.; Yang, L.; Zhuang, S. Study on the combustion characteristic of adhesive polystyrene. Appl. Mech. Mater. 2014, 664, 191-193. [CrossRef]

14. Muthadhi, A.; Kothandaraman, S. Experimental investigations on polymer-modified concrete subjected to elevated temperatures. Mater. Struct. 2014, 47, 977-986. [CrossRef]

15. Zhang, H.Y.; Kodur, V.; Wu, B.; Cao, L.; Wang, F. Thermal behavior and mechanical properties of geopolymer mortar after exposure to elevated temperatures. Constr. Build. Mater. 2016, 109, 17-24. [CrossRef]

16. Berardi, U.; Meacham, B.J.; Dembsey, N.A.; You, Y.G. Fire performance assessment of a fiber reinforced polymer wall panel used in a single family dwelling. Fire Technol. 2014, 50, 1607-1617. [CrossRef]

17. Chang, J.H.; Choi, S.M. Workability evaluation of the inorganic surface preparation materials including EVA redispersible polymer powder for wall. J. Archit. Inst. Korea Struct. Constr. 2013, 29, 53-62.

18. Kim, W.K.; Kim, D.M. Properties of acrylic emulsion mortar using pyroligneous liquid of wood by-product. J. Korea Soc. Waste Manag. 2014, 31, 70-78. [CrossRef]

19. Korean Agency for Technology and Standards (KATS). Cement Filling Compound for Surface Preparation; Korean Standard KS F 4716; Korean Agency for Technology and Standards (KATS): Seoul, Korea, 2016.

20. Park, J.H.; Singh, J.K.; Lee, H.S. Ozone Resistance, Water Permeability, and Concrete Adhesion of Metallic Films Sprayed on a Concrete Structure for Advanced Water Purification. Coatings 2017, 7, 41. [CrossRef] 
21. Min, S.H.; Kim, M.S. A study on the fire risk assessment of EIFS by cone calorimeter test \& single burning item test. J. Korea Saf. Manag. Sci. 2010, 12,1-9.

22. Lee, J.C.; Park, J.C.; Song, H. Effect of external thermal insulation composite system with a non-combustible calcium silicate based mineral on the mitigation for reducing fast spread of flame. J. Korea Inst. Build. Constr. 2016, 16, 397-403. [CrossRef]

23. Lee, J.C.; Seo, J.S.; Kim, S.B. Study on flame retardancy and thermal resistance properties of phenolic foam and polyurethane foam. J. Korean Inst. Gas 2013, 17, 35-41. [CrossRef]

24. Zhang, Z.; Shi, G.; Wang, S.; Fang, X.; Liu, X. Thermal energy storage cement mortar containing n-octadecane/expanded graphite composite phase change material. Renew. Energy 2013, 50, 670-675. [CrossRef]

25. Zhang, Y.P.; Ding, J.H.; Wang, X.; Yang, R.; Lin, K.P. Influence of additives on thermal conductivity of shape-stabilized phase change material. Sol. Energy Mater. Sol. Cells 2006, 90, 1692-1702. [CrossRef]

26. He, Y.; Zhang, X.; Zhang, Y.J.; Song, Q.; Liao, X.M. Utilization of lauric acid-myristic acid/expanded graphite phasechange materials to improve thermal properties of cement mortar. Energy Build. 2016, 133, 547-558. [CrossRef]

27. Pincemin, S. Highly conductive composites made of phase change materials and graphite for thermal storage. Sol. Energy Mater. Sol. Cells 2008, 92, 603-613. [CrossRef]

28. Sari, A.; Karaipekli, A. Thermal conductivity and latent heat thermal energy storage characteristics of paraffin/expanded graphite composite as phase change material. Appl. Therm. Eng. 2007, 27, 1271-1277. [CrossRef]

29. Xia, L.; Zhang, P.; Wang, R.Z. Preparation and thermal characterization of expanded graphite/paraffin composite phase change material. Carbon 2010, 48, 2538-2548. [CrossRef]

30. Vahabi, H.; Sae, M.R.; Formelac, K.; Cuestad, J.M. Flame retardant epoxy/halloysite nanotubes nanocomposite coatings: Exploring low-concentration threshold for flammability compared to expandable graphite as superior fire retardant. Prog. Org. Coat. 2018, 119, 8-14. [CrossRef]

31. Wang, X.; Kalali, E.N.; Wan, J.T.; Wang, D.Y. Carbon-family materials for flame retardant polymeric materials. Prog. Polym. Sci. 2017, 69, 22-46. [CrossRef]

32. Kashiwagi, T.; Du, F.; Winey, K.I.; Groth, K.M.; Shields, J.R.; Bellayer, S.P.; Kim, H.; Douglas, J.F. Flammability properties of polymer nanocomposites with singlewalled carbon nanotubes: Effects of nanotube dispersion and concentration. Polymer 2005, 46, 471-481. [CrossRef]

33. Korean Agency for Technology and Standards (KATS). Determination of the Water Absorption Coefficient of Building Materials; Korean Standard KS F 2609; Korean Agency for Technology and Standards (KATS): Seoul, Korea, 2018.

34. Kang, H.J.; Song, M.S.; Lee, S.K. A Study on the Watertightness of Shotcrete with Watertightness Materials. J. Korean Ceram. Soc. 2008, 45, 35-41. [CrossRef]

35. Chuigen, G.; Lin, Z.; Jianxiong, L. Effects of expandable graphite and modified ammonium polyphosphate on the flame-retardant and mechanical properties of wood flour-polypropylene composites. Polym. Polym. Compos. 2013, 21, 449-456.

36. Yang, E.H.; Yang, Y.; Li, V.C. Use of high volumes of fly ash to improve ecc mechanical properties and material greenness. ACI Mater. J. 2007, 104, 303-311.

(C) 2019 by the authors. Licensee MDPI, Basel, Switzerland. This article is an open access article distributed under the terms and conditions of the Creative Commons Attribution (CC BY) license (http://creativecommons.org/licenses/by/4.0/). 